\title{
Determination of high-temperature and low-humidity treatment time for larch boxed-heart timber
}

\author{
Chun-Won Kang ${ }^{1}$, Chengyuan $\mathrm{Li}^{2 *}$ and Yao-Xing Sun ${ }^{2}$
}

\begin{abstract}
The larch boxed-heart timbers with a cross section of $100 \times 100 \mathrm{~mm}$ were dried after steamed at $100^{\circ} \mathrm{C}$ dry-bulb temperature and $0{ }^{\circ} \mathrm{C}$ wet-bulb depression for $5 \mathrm{~h}$, and then dried at $120^{\circ} \mathrm{C}$ dry-bulb temperature and $30^{\circ} \mathrm{C}$ wet-bulb depression for 8,12 and $16 \mathrm{~h}$, respectively, in order to determine optimal treatment time for the timber. This study indicated that the pretreatment of 12 and $16 \mathrm{~h}$ prevented both the surface and internal check of the timber. However, the pretreatment delayed drying time by at least $19 \%$.
\end{abstract}

Keywords: Pretreatment time, Surface check, Internal check

\section{Introduction}

High-temperature and low-humidity (HT-LH) treatment prior to kiln drying has shown promising results in controlling the surface check of boxed-heart timber because a large drying set was formed at the surface layer of the timber [1-4]. But this pretreatment usually incurred internal checking. Large internal checks are undesirable for the strength properties of timber. Ido et al. [5] reported that internal checks had little effect on bending strength, but had a significant effect on shear strength.

In order to prevent or largely reduce surface and internal check of boxed-heart timber, some researches on the optimal conditions of HT-LH pretreatment have been conducted. Hermawan et al. [6] found that the surface checks tended to decrease while the internal checks of sugi boxed-heart timbers tended to increase as pretreatment temperature and time increased. The causes for trend above can be believed as following. As pretreatment temperature and/or time increase, drying set is also increased $[7,8]$. Although drying set can reduce or

\footnotetext{
*Correspondence: Iswforest@hotmail.com

2 Department of Wood Science and Engineering, Beihua University, Room

113, Yifu building, No. 3999, Binjiang East Road, Jilin City 132013, Jilin

Province, People's Republic of China

Full list of author information is available at the end of the article
}

prevent surface checking, when it is increased to some degree, it will increase internal tensile stresses during the last stage of drying and can incur internal checking. Therefore, it is critical to seek out optimal temperature and time of HT-LH treatment for specified size and species of boxed-heart timbers in order to prevent both surface and internal check. Katagiri et al. [3] effectively controlled the surface checks on sugi boxed-heart square timbers by employing the pretreatment of $120{ }^{\circ} \mathrm{C}$ drybulb temperature and $30^{\circ} \mathrm{C}$ wet-bulb depression for $12 \mathrm{~h}$, but did not report the result of the internal checks. Hermawan et al. reported that pretreatment at a temperature of $135^{\circ} \mathrm{C}$ for $10 \mathrm{~h}$ or $150{ }^{\circ} \mathrm{C}$ for $7 \mathrm{~h}$ was effective in preventing surface checks of sugi boxed-heart square timbers, however, the internal checks were observed in most specimens. According to the study of Kuroda [9], HT$\mathrm{LH}$ treating time was $10 \mathrm{~h}$ at minimum to prevent surface checks, and $30-40 \mathrm{~h}$ at maximum to control internal checks of the sugi boxed-heart timbers with a cross section of $132 \times 132 \mathrm{~mm}$, and the initial MC (moisture content) of $80-100 \%$ under the condition of $120^{\circ} \mathrm{C}$ dry-bulb temperature and $30{ }^{\circ} \mathrm{C}$ wet-bulb depression. Although Kuroda gave the range of HT-LH treating time to prevent both the surface checks and internal checks of sugi boxed-heart timbers, he did not provide optimal HT-LH treating time. A similar study was reported by Hokkaido
SpringerOpen (c) The Author(s) 2020. This article is licensed under a Creative Commons Attribution 4.0 International License, which permits use, sharing, adaptation, distribution and reproduction in any medium or format, as long as you give appropriate credit to the original author(s) and the source, provide a link to the Creative Commons licence, and indicate if changes were made. The images or other third party material in this article are included in the article's Creative Commons licence, unless indicated otherwise in a credit line to the material. If material is not included in the article's Creative Commons licence and your intended use is not permitted by statutory regulation or exceeds the permitted use, you will need to obtain permission directly from the copyright holder. To view a copy of this licence, visit http://creativeco mmons.org/licenses/by/4.0/. 
Forest Experimental Station [10]. Therefore, the objective of this study was to determine proper pretreatment time for the larch boxed-heart timbers with a cross section of $100 \times 100 \mathrm{~mm}$ in order to prevent both the surface and internal check.

\section{Materials and procedures}

80 pieces of boxed-heart square timbers with the dimension of $100 \times 100 \times 1700 \mathrm{~mm}$ were sawn from green Japanese larch (Larix kaempferi G.) logs with a length of $1700 \mathrm{~mm}$ and an average diameter of $15 \mathrm{~cm}$. And then 20-mm-thick cross sections were cut at length position about $300 \mathrm{~mm}$ from each end of the timbers to measure the green $\mathrm{MC}$ of each timber. The ends of the specimens with the dimension of $100 \times 100 \times 1000 \mathrm{~mm}$ were coated with waterproof paint. The average green MC of specimens was $38.10 \%$ while the average final MC of specimens was $12.95 \%$. Next, total 60 pieces of specimens, 20 pieces for each HT-LH treatment, were steamed at $100{ }^{\circ} \mathrm{C}$ dry-bulb temperature and $0{ }^{\circ} \mathrm{C}$ wet-bulb depression for $5 \mathrm{~h}$. And then they were dried at $120^{\circ} \mathrm{C}$ dry-bulb temperature and $30{ }^{\circ} \mathrm{C}$ wet-bulb depression for $8 \mathrm{~h}, 12 \mathrm{~h}$ and $16 \mathrm{~h}$ in a forced-air drier (SKD-90HPT, Shinshiba, Asahikawa Japan), respectively. Control (untreated) specimens were stacked in the same drier and dried together with HT-LH pretreated specimens using the drying schedule (Table 1). 8 pieces of the specimens with high initial MC, 2 pieces of the specimens from each HT-LH treatment and control, were pulled out of the drier and weighed at intervals of $24 \mathrm{~h}$ to measure MCs during drying.

After the end of drying, final MCs, the checks of specimens were measured. The widths and lengths of all surface checks were measured using a digital caliper, and the total surface check area of each specimen was calculated. After determining the surface checks, each specimen was cut in the middle by cross-sectional cutting and the total number of internal checks was counted and their lengths were measured using the caliper.

\section{Results and discussion Drying time}

The MCs corresponding to minus $24 \mathrm{~h}$ in Fig. 1 were those of the specimens before HT-LH pretreatment after presteaming. The final MC of specimens was $12.36 \%$ of control specimens, $12.38 \%$ of the specimens pretreated for $8 \mathrm{~h}, 13.01 \%$ of the specimens pretreated for $12 \mathrm{~h}$ and $14.06 \%$ of the specimens pretreated for $16 \mathrm{~h}$. The drying time of specimens was 17 days $(408 \mathrm{~h})$ for control specimens, 21 days $(504 \mathrm{~h})$ for the specimens pretreated for $8 \mathrm{~h}$ and over 21 days for the specimens pretreated for 12 and $16 \mathrm{~h}$ (Fig. 1), which indicates that the drying time of the pretreated timbers is delayed by at least $19 \%$ compared to that of control specimens. This trend can be attributed to slower drying rate of $\mathrm{HT}-\mathrm{LH}$-treated specimens. The observation above was in agreement with the finding of Hermawan et al. [6].

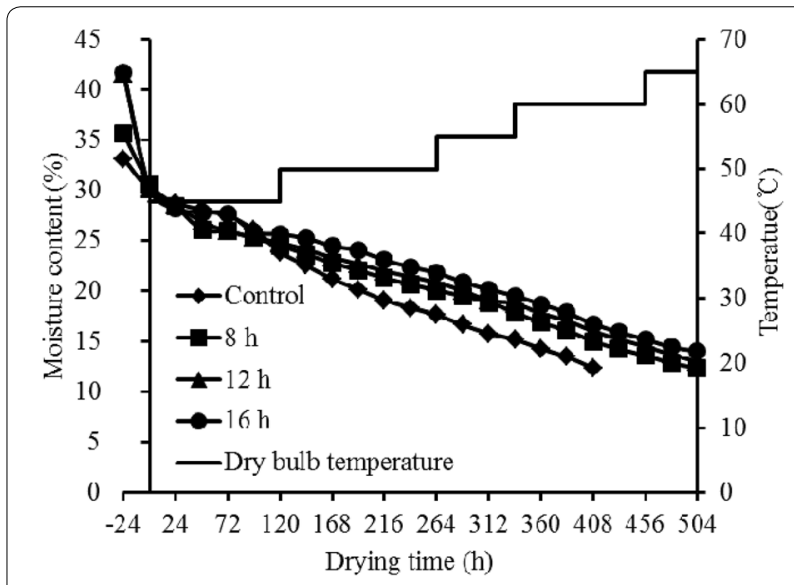

Fig. 1 Drying curves of control and pretreated specimens

Table 1 Drying schedule

\begin{tabular}{llcrr}
\hline Drying stage & Moisture content range (\%) & Dry-bulb temperature $\left({ }^{\circ} \mathbf{C}\right)$ & Wet-bulb depressions $\left({ }^{\circ} \mathbf{C}\right)$ & Treatment time $(\mathbf{h})$ \\
\hline Presteaming & & 100 & 0 & 5 \\
HT-LH & 120 & 30 & $8,12,16$ \\
1 & Above 40 & 45 & 3 & 48 \\
2 & $40-30$ & 45 & 4 & 72 \\
3 & $30-25$ & 50 & 6 & 96 \\
4 & & & 8 & 48 \\
5 & $25-20$ & 55 & 8 & 72 \\
6 & $20-15$ & 60 & 10 & 48 \\
8 & Below 15 & 60 & 14 & 72 \\
\hline
\end{tabular}




\section{Drying rate}

The F-test of drying rate indicated that the difference in average drying rate between $\mathrm{HT}-\mathrm{LH}$-treated specimens (pretreated for $8 \mathrm{~h}$, for $12 \mathrm{~h}$, and for $16 \mathrm{~h}$ ) and control specimens was significant during whole drying period $(P<0.0001)$. As seen in Fig. 2, the average drying rate of pretreated specimens was slower than that of control specimens during whole drying period, and tended decrease as pretreating time increased. This tendency could be attributed to the changed microfibrils and components in the surface layers of the pretreated specimens during presteaming and pretreating. This is a subject to be further studied in the near future.

\section{Surface check}

Most of the specimens pretreated for 12 and $16 \mathrm{~h}$ were free surface checks in spite of the some slight surface checks which occurred before drying because of low initial MC (Table 2). The surface checks on HT-LH-treated specimens were much less than those on control specimens, and tended to decrease as HT-LH treating time

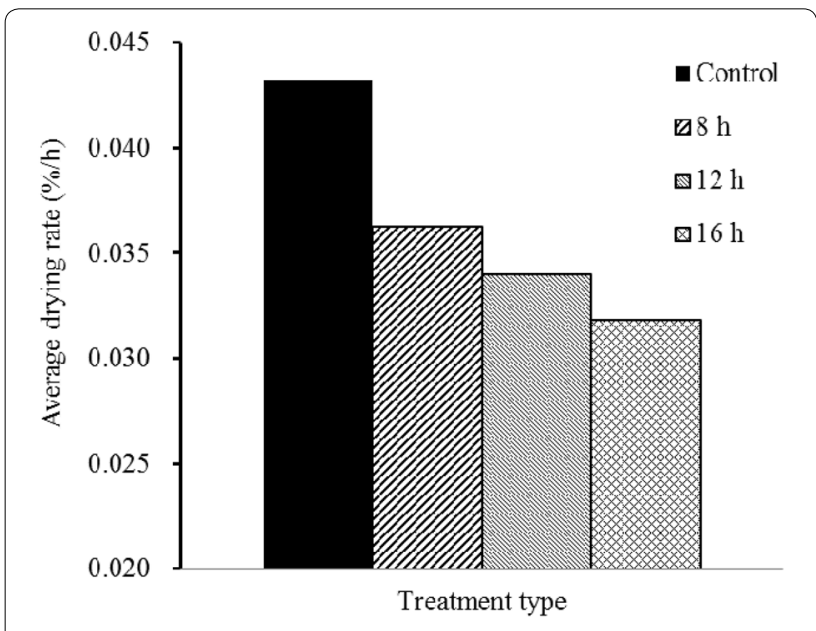

Fig. 2 Average drying rates of control and pretreated specimens increased (Table 2). This trend can be attributed to the large drying set formed inside the surface layers of HTLH-treated timbers, which relaxes large tensile stresses. Thus, the drying set prevented or reduced the surface checks. Moreover, as the treating time of HT-LH treatment increased, the tensile creep also became larger, which enhanced an ability of preventing or reducing surface checks.

\section{Internal check}

The internal checks inside HT-LH-treated specimens were much less than that inside control specimens. For pretreated specimens, only two internal checks were found for the specimens pretreated for $8 \mathrm{~h}$, and no internal checks were observed for the specimens pretreated for 12 and $16 \mathrm{~h}$ (Table 2). Although the drying set, produced by HT-LH treatment, can control surface checks, large drying set is undesirable because it can induce internal checking. In this experiment, the proper HT-LH treating time was $12-16 \mathrm{~h}$ for small larch boxed-heart square timbers sawn from the log with a diameter of $15 \mathrm{~cm}$.

\section{Conclusions}

The larch boxed-heart square timbers with a cross section of $100 \times 100 \mathrm{~mm}$ were kiln dried after steamed at $100{ }^{\circ} \mathrm{C}$ dry-bulb temperature and $0{ }^{\circ} \mathrm{C}$ wet-bulb depression for $5 \mathrm{~h}$, and then pretreated at $120^{\circ} \mathrm{C}$ dry-bulb temperature and $30{ }^{\circ} \mathrm{C}$ wet-bulb depression for $8 \mathrm{~h}, 12 \mathrm{~h}$ and $16 \mathrm{~h}$, respectively, to develop optimal pretreatment time for small larch boxed- heart square timbers. The results of this study were as following:

1. HT-LH pretreatment at $120{ }^{\circ} \mathrm{C}$ dry-bulb temperature and $30{ }^{\circ} \mathrm{C}$ wet-bulb depression for 12 and $16 \mathrm{~h}$ prevented both the surface and internal checks of the larch boxed-heart square timbers with a cross section of $100 \times 100 \mathrm{~mm}$, and with relative low initial moisture content.

Table 2 Checks of larch timbers after drying

\begin{tabular}{|c|c|c|c|c|c|c|}
\hline \multirow[t]{2}{*}{ Treatment } & \multicolumn{3}{|c|}{ Surface check } & \multicolumn{3}{|c|}{ Internal check } \\
\hline & Area $\left(\mathrm{mm}^{2}\right)$ & Standard deviation & Sum total & Area $\left(\mathrm{mm}^{2}\right)$ & Standard deviation & Sum total \\
\hline Control & 26.30 & 24.46 & 17 & 10.00 & 2.32 & 6 \\
\hline $8 \mathrm{~h}$ & 0.08 & 0.07 & 5 & 3.00 & 0.76 & 2 \\
\hline $12 \mathrm{~h}$ & 0.06 & 0.04 & 3 & 0.00 & 0.00 & \\
\hline $16 \mathrm{~h}$ & 0.02 & 0.00 & 1 & 0.00 & 0.00 & \\
\hline
\end{tabular}


2. HT-LH pretreatment delayed the drying time by at least $19 \%$ because of slower drying rate of the pretreated timbers.

\section{Acknowledgements}

This research was supported by Basic Science Research Program through the National Research Foundation of Korea (NRF) funded by the Ministry of Education (NRF-2019R111A3A02059471).

\section{Authors' contributions}

CW Kang provided whole experiment plan and wrote the main manuscript text. CL implemented the experiment. YXS took part in the experiment and prepared tables and figures. All authors read and approved the final manuscript.

\section{Funding}

Not applicable.

\section{Availability of data and materials}

The data sets generated during and/or analysed during the current study are available from the corresponding author upon request.

\section{Competing interests}

The authors declare no competing interests.

\section{Author details}

1 Department of Housing Environmental Design, and Research Institute of Human Ecology, College of Human Ecology, Jeonbuk National University, Room 504, Building No. 7-1, Baekje-daero, Deokjin-gu, 561-756 Jeonju-si, Jeollabuk-do, Republic of Korea. ${ }^{2}$ Department of Wood Science and Engineering, Beihua University, Room 113, Yifu building, No. 3999, Binjiang East Road, Jilin City 132013, Jilin Province, People's Republic of China.

Received: 14 September 2019 Accepted: 2 March 2020

Published online: 16 March 2020

\section{References}

1. Yoshida T, Hashizume T, Fujimoto N (2000) High-temperature drying characteristic on boxed-heart square timber of karamatsu and sugiinfluence of high temperature conditions with low humidity on drying properties. Wood Ind 55:357-362

2. Katagiri $Y$, Fujimoto $N$, Murase $Y$ (2005) The effect of pre-treatment time in a high-temperature and low-humidity condition on the quality of sugi dried boxed-heart square timber. Wood Ind 60:262-266

3. Katagiri Y, Fujimoto N, Murase Y (2007) Effect of the treatment temperature on the surface drying set of sugi boxed-heart square timber. Dry Tech 25:507-510

4. Lee NH, Li C, Zhao XF (2010) Effect of pretreatment with high temperature and low humidity on drying time and prevention of checking during radio frequency/vacuum drying of Japanese red cedar pillar. J Wood Sci 56:19-24

5. Ido H, Nagao H, Kato H (2005) Effect of the internal check on the shear strength of sugi lumber. Wood Ind 60:170-174

6. Hermawan A, Fujimoto N, Sakagami H (2012) Effects of high-temperature and low- humidity pretreatment on the drying properties of sugi boxedheart timber with black-colored heartwood. Dry Tech 30:780-786

7. McMillen JM (1955) Drying stress in red oak. For Prod J 5:71-76

8. Yifu T, Simpson WT (1990) Perpendicular to grain rheological behavior of loblolly pine in press drying. Wood Fiber Sci 22:326-342

9. Kuroda N (2007) Development of fundamental research on of boxedheart square timber of sugi (Cryptomeria japonica). Mokuzai Gakkaishi 53:243-253 (in Japanese)

10. Tsuchihashi $\mathrm{H}$, Nakajima A (2005) Relation between drying conditions and strength of square posts of karamatsu in high-temperature setting method. J Hokkaido For Prod Res Inst 19:22-26 (in Japanese)

\section{Publisher's Note}

Springer Nature remains neutral with regard to jurisdictional claims in published maps and institutional affiliations.

\section{Submit your manuscript to a SpringerOpen ${ }^{\circ}$ journal and benefit from:}

- Convenient online submission

- Rigorous peer review

- Open access: articles freely available online

- High visibility within the field

- Retaining the copyright to your article

Submit your next manuscript at $\boldsymbol{\nabla}$ springeropen.com 